\title{
Eastern Indo-Aryan Language
}

National Cancer Institute

\section{Source}

National Cancer Institute. Eastern Indo-Aryan Language. NCI Thesaurus. Code C161843.

A group of Indo-Aryan languages that derive from Magadhan Apabhramiśa Prakrit. 